\begin{tabular}{|c|c|}
\hline NDBR & Management and Business Review \\
\hline $\begin{array}{l}\text { MANAGEMENT \& } \\
\text { BUSINESS REVIEW }\end{array}$ & $\begin{array}{c}\text { Available at } \frac{\text { http://ejournal.unikama.ac.id/index.php/mbr }}{\text { ISSN: } 2541-5808 \text { (online) }}\end{array}$ \\
\hline
\end{tabular}

\title{
Pengaruh pengembangan karir terhadap motivasi kerja karyawan melalui kepuasan kerja
}

\section{Farita Dian Sofa Safitri}

Program Studi Manajemen, Fakultas Ekonomika dan Bisnis Universitas Kanjuruhan Malang, Indonesia

e-mail: $\underline{\text { faritadian@gmail.com }}$

$\begin{array}{ll}\text { Article Info: } \\ \text { Receive } & : \text { Maret } 2018 \\ \text { Revised } & : \text { April } 2018 \\ \text { Accepted } & : \text { Mei } 2018 \\ \text { Published } & : \text { Juni } 2018 \\ \text { DOI } & : \text { 10.21067/mbr.v2i1.4731 } \\ \text { Copyright } & : \text { Management and } \\ & \text { Business Review }\end{array}$

Keywords:

Pengembangan karir, Motivasi

Kerja, Kepuasan Kerja

\begin{abstract}
This study aims to determine the effect of career development on work motivation, and to analyze job satisfaction as a mediator of career development on work motivation. This is a quantitative research with explanatory research type, research at the Center for Community and Village Empowerment in Malang. With a total sample of 31 employees of the Center for Community and Village Empowerment in Malang. The data collection technique used a questionnaire, which was arranged with a Likert scale. The data analysis used is path analysis. The results show that career development has a significant effect on employee motivation, and job satisfaction has a significant influence on career development on employee motivation.
\end{abstract}

\begin{abstract}
Abstrak: Penelitian ini bertujuan untuk mengetahui pengaruh pengembangan karir terhadap motivasi kerja, dan menganalisis kepuasan kerja sebagai mediasi pengembangan karir terhadap motivasi kerja. Merupakan penelitian Kuantitatif dengan jenis explanatory research, penelitian pada Balai Besar Pemberdayaan Masyarakat dan Desa di Malang. Dengan jumlah sampel sebanyak 31 pegawai Balai Besar Pemberdayaan Masyarakat dan Desa di Malang. Teknik pengumpulan data menggunakan kuesioner, yang disusun dengan Skala Likert. Analisis data yang digunakan adalah analisis jalur (Path Analysis). Hasil menunjukkan bahwa pengembangan karir berpengaruh signifikan terhadap motivasi kerja karyawan, dan kepuasan kerja memdiasi pengaruh pengembangan karir terhadap motivasi kerja karyawan.
\end{abstract}

\section{Pendahuluan}

Pemberian motivasi sangat diperlukan, apabila karyawan memiliki produktivitas dan motivasi kerja yang tinggi, maka organisasi pun akan semakin berkembang, yang akan menghasilkan kinerja dan pencapaian yang baik bagi 
organisasi. Di sisi lain, organisasi tidak dapat berjalan baik apabila karyawan bekerja tidak produktif, artinya karyawan tidak memiliki semangat kerja yang tinggi, tidak ulet dalam bekerja dan memiliki moril yang rendah. Menurut Hasibuan (2016) motivasi merupakan pemberian daya penggerak yang menciptakan gairah kerja seseorang agar mereka mau bekerja sama, bekerja efektif, dan berintegrasi dengan segala daya dan upaya untuk mencapai kepuasan yang diinginkan. Sejalan dengan penelitian motivasi yang dilakukan oleh Isyanto \& Sungkono (2013) yang membuktikan bahwa pengembangan karir berpengaruh positif terhadap motivasi kerja, dengan nilai koefisien determinasi sebesar 49 persen.

Pegawai dan organisasi merupakan dua hal yang tidak dapat dipisahkan, karyawan memegang peran utama dalam menjalankan roda kehidupan organisasi. Apabila karyawan memiliki produktivitas yang tinggi, maka organisasi akan semakin berkembang, dan akhirnya menghasilkan kinerja dan pencapaian yang baik bagi organisasi. Hal semacam itu pada akhirnya berdampak pada kepuasan kerja yang menyangkut sikap seseorang mengenai pekerjaannya. Karena menyangkut sikap, pengertian kepuasan kerja mencakup berbagai hal seperti kondisi dan kecenderungan perilaku seseorang. Seperti pada penelitian yang dilakukan oleh Djamaludin (2009), yang membuktikan bahwa pengembangan karir berpengaruh signifikan terhadap kepuasan kerja, dengan nilai koefisien 0,94\%. Kepuasan kerja tidak tampak serta nyata, tetapi dapat diwujudkan dalam suatu hasil pekerjaan. Salah satu masalah yang sangat penting dalam bidang psikologi adalah mendorong karyawan untuk bekerja dengan lebih produktif. Kepuasan kerja akan berbeda pada masing-masing individu. Menurut Martoyo (2007) kepuasan kerja atau job salisfaction adalah keadaan emosional karyawan di mana terjadi ataupun tidak terjadi titik temu antara nilai balas jasa kerja karyawan dari organisasi dengan tingkat nilai balas jasa yang memang diinginkan oleh karyawan yang bersangkutan. Balas jasa kerja karyawan ini, baik yang berupa finansial maupun yang nonfinansial.

Dorongan orang bekerja pada suatu organisasi adalah karena disana ada kesepatan untuk maju. Sudah menjadi sifat dasar manusia pada umumnya untuk menjadi lebih baik, lebih maju dari posisi yang dipunyai pada saat ini. Karyawan menginginkan suatu kemajuan dalam hidupnya. Rivai \& Sagala (2009) mendefinisikan pengembangan karir adalah proses peningkatan kemampuan kerja individu yang dicapai dalam rangka mencapai karir yang diinginkan. Sedangkan menurut Mathis \& Jackson (2009) mengemukakan bahwa pengertian karir adalah rangkaian posisi yang berkaitan dengan kerja yang ditempati seseorang sepanjang hidup organisasi harus mendukung para karyawan untuk mengembangkan karir mereka, karena hal ini sangat vital dalam menjaga loyalitas, terutama karena saat ini semakin sulit dan langka mencari tenaga kerja yang berbakat. Penelitian yang dilakukan oleh Bianca \& Susihono (2012), yang membuktikan bahwa pengembangan karir berpengaruh signifikan terhadap kepuasan dengan nilai signifikansi 0,421. Manajer harus berusaha membantu karyawannya untuk dapat bekerja seefektif 
mungkin dan menciptakan iklim kerja yang memungkinkan tercapainya pengembangan karier dan kepuasaan kerja.

Balai Besar Pemberdayaan Masyarakat dan Desa Malang yang biasa disingkat BBPMD Malang sebagai UPT Direktorat Jenderal Bina Pemerintah Desa Kementrian Dalam Negeri di bidang pelatihan pemerintahan desa, seperti pelatihan manajemen pemerintah desa, BPD, perangkat desa, Lembaga Kemasyarakatan Desa, PKK, dan BUMDES dalam rangka penguatan kapasitas SDM pemerintahan dan lembaga kemasyarakatan desa. Mengingat berkembangnya suatu daerah sangat dipengaruhi oleh sumberdaya manusia, organisasi pemerintah yang mempunyai karyawan yang berstatus ASN/PNS dan non PNS dalam suatu lembaga yang memiliki kinerja berdasarkan tugas pokok dan fungsinya., mengembangkan organisasi berdasarkan peraturan kepegawaian yang diatur berdasarkan UU no 5 th 2014 tentang Aparatur Sipil Negara (ASN), dimana karyawan melakukan pekerjaan sesuai dengan tugas pokok dan fungsi sesuai dengan jabatan pada masing-masing karyawan.

Berdasarkan uraian diatas, maka tujuan penelitian adalah untuk menganalisis pengaruh pengembangan karir terhadap motivasi kerja karyawan dimediasi kepuasan kerja.

\section{Pengembangan karir dan motivasi kerja}

Pengembangan karir adalah proses peningkatan kemampuan kerja individu yang dicapai dalam rangka mencapai karir yang diinginkan (Rivai, Veithzal dan Sagala, 2009). Faktor-faktor yang mampu mempengaruhi Pengembangan karir meliputi : prestasi kerja, eksposur, jaringan kerja, kesetiaan terhadap organisasi, pembimbing dan sponsor, peluang untuk tumbuh. Menurut Sule \& Saefullah (2005) motivasi adalah dorongan atau alasan seseorang untuk melakukan suatu kegiatan. Faktor-faktor penentu motivasi kerja, yaitu : kebutuhan fisiologis, kebutuhan rasa aman, kebutuhan social, kebutuhan penghargaan, kebutuhan aktualisasi diri.

Penelitian Kurniawan et al. (2018) menyatakan bahwa pengembangan karir dan kompensasi adalah faktor yang mempengaruhi motivasi maupun kinerja karyawan. Namun penelitian Dewi \& Utama (2016) menjelaskan bahwa pengembangan karir tidak mempengaruhi motivasi dan bukan sebagai mediasi hubungan pengembangan karir dan kinerja karyawan. Haryani (2012) menyatakan bahwa pengembangan karir berpengaruh terhadap motivasi kerja.

H1. Pengembangan karir berpengaruh signifikan terhadap motivasi kerja karyawan

Penelitian Manoppo (2015) menyatakan bahwa pengembangan karir tidak berpengaruh signifikan terhadap kepuasan kerja, namun penelitian Lisdiani \& Ngatno (2017), Akhmal et al. (2018) dan Bahri \& Nisa (2017) menyatakan bahwa pengembangan karir akan mempengaruhi kepuasan kerja karyawan.

H2. Pengembangan karir berpengaruh signifikan terhadap kepuasan kerja karyawan

\section{Kepuasan kerja dan Motivasi Kerja}


Menurut Hasibuan (2016) adalah sikap emosional yang menyenangkan dan karyawan mencintai pekerjaanya. Kepuasan kerja karyawan harus diciptakan sebaik-baiknya supaya moral kerja, dedikasi, kecintaan, dan kedisplinan karyawan meningkat. Faktor-faktor yang dapat memicu kepuasan kerja meliputi : komponen gaji dan upah, peralatan yang menunjang pekerjaan, promosi karir, hubungan dengan atasan. Hasil penelitian menjelaskan bahwa adanya hubungan antara kepuasan kerja dan motivasi kerja (Afifah \& Al Musadieq, 2017; Lie, 2018).

H3. Kepuasan kerja berpengaruh positif terhadap motivasi kerja karyawan

\section{Metode}

Penelitian ini menggunakan metode explanatory research (penelitian penjelasan) dengan menggunakan pendekatan kuantitatif. Dengan menggunakan sampel jenuh dengan 31 orang pegawai pegawai Balai Besar Pemberdayaan Masyarakat dan Desa di Malang. Teknik pengumpulan data menggunakan kuesioner yang disusun dengan Skala Likert 5 poin. Variabel penelitian terdiri dari variabel bebas pengembangan karir dan kepuasan kerja, sedangkan variabel terikat adalah motivasi kerja. Teknik analisis data yang digunakan adalah analisis deskriptif dan Analisis Jalur (path analysis).

\section{Hasil}

\section{Analisis Deskriptif}

Berdasarkan hasil perhitungan statistik deskriptif diperoleh ringkasan hasil analisis deskriptif tentang pengembangan karir, kepuasan kerja, dan motivasi kerja.

\section{Pengembangan Karir}

Variabel pengembangan karir diukur dari indikator prestasi kerja, eksposur, jaringan kerja, kesetiaan terhadap organisasi, pembimbing dan sponsor, serta peluang untuk tumbuh, adapun indikator yang dominan adalah pembimbing dan sponsor dengan adanya jenjang karir terhadap pegawai. Sedangkan indikator yang dinilai rendah adalah eksposur (dan peluang untuk tumbuh, melaporkan tugas secara tertulis dan melakukan pelatihan atau kursus.

\section{Kepuasan Kerja}

Variabel kepuasan kerja diukur dengan indikator komponen gaji dan upah, peralatan yang menunjang pekerjaan, promosi karir, dan hubungan dengan atasan, menunjukkan bahwa variabel kepuasan kerja terutama didukung oleh peralatan yang menunjang pekerjaan dengan adanya sarana dan prasarana yang layak digunakan. Adapun indikator kepuasan kerja yang terendah adalah hubungan dengan atasan, dengan adanya tenggang rasa antara pegawai dengan atasan. 


\section{Motivasi Kerja}

Variabel motivasi kerja diukur dari indikator kebutuhan fisiologis, kebutuhan rasa aman, kebutuhan social, kebutuhan penghargaan, kebutuhan aktualisasi diri menunjukkan bahwa variabel motivasi kerja terutama didukung dari indikator kebutuhan penghargaan. Sedangkan indikator yang dinilai rendah adalah adalah belum terpenuhinya kebutuhan rasa aman khususnya keselamatan kerja.

\section{Hasil Analisis Regresi}

Berdasarkan hasil analisis Regresi yang disajikan pada tabel 1 dapat dijelaskan bahwa model Regresi yang digunakan akurat, dilihat dari hasil Uji F dengan nilai signifikansi 0,000 $<0,05$. Model regresi dapat menjelaskan besarnya kontribusi pengembangan karir dan kepuasan kerja terhadap perubahan motivasi yaitu sebesar 52,1\% (nilai $\mathrm{R}^{2}$ ), sedangkan sisanya dijelaskan variabel lain.

\section{Tabel 1. Hasil Analisis Regresi}

\begin{tabular}{lclrll}
\hline Variabel Bebas & B & Beta & t & Sig t & Keterangan \\
\hline$(\mathrm{x})-(\mathrm{y} 1)$ & 0,318 & 0,587 & 3,903 & 0,001 & Signifikan \\
$(\mathrm{y} 1)-(\mathrm{y} 2)$ & 0,519 & 0,442 & 2,830 & 0,009 & Signifikan \\
$(\mathrm{x})-(\mathrm{y} 2)$ & 0,250 & 0,393 & 2,518 & 0,018 & Signifikan \\
\hline
\end{tabular}

Variabel Terikat: motivasi Kerja (y2)

R Square $=0,521$

$\mathrm{F} \quad=17,320$

Sig F $\quad=0,000$

Sumber : Data diolah

Koefesien jalur pengembangan karir sebesar 0,587 menunjukan bahwa pengembangan karir memiliki pengaruh positif terhadap kepuasan kerja, artinya kenaikan pengembangan karir akan menyebabkan kepuasan kerja meningkat.

Koefisien jalur kepuasan kerja sebesar 0,442 menunjukan bahwa kepuasan kerja memiliki pengaruh positif terhadap motivasi kerja, artinya kenaikan kepuasan kerja akan menyebabkan motivasi kerja meningkat.

Koefisien jalur pengembangan karir sebesar 0,393 menunjukan bahwa pengembangan karir memiliki pengaruh positif terhadap motivasi kerja, artinya kenaikan pengembangan karir akan menyebabkan motivasi kerja meningkat.

\section{Uji Hipotesis}

Hasil uji hipotesis variabel pengembangan karir diperoleh nilai signifikansi $0,018<0,05$ berarti ada pengaruh yang signifikan dari variabel pengembangan karir terhadap motivasi kerja, dengan demikian dapat disimpulkan $\mathrm{H}_{1}$ diterima, artinya bahwa pengembangan karir berpengaruh signifikan terhadap motivasi kerja karyawan melalui kepuasan kerja di Balai Besar Pemberdayaan Masyarakat dan Desa Malang. 
Varibel pengembangan karir terhadap kepuasan kerja diperoleh nilai signifikansi sebesar 0,001 < 0,05 berarti ada pengaruh yang signifikan dari variabel pengembangan karir terhadap kepuasan kerja. Dengan demikian dapat disimpulkan bahwa $\mathrm{H}_{2}$ diterima, bahwa pengembangan karir berpengaruh signifikan terhadap kepuasan kerja karyawan di Balai Besar Pemberdayaan Masyarakat dan Desa Malang.

Variabel kepuasan kerja terhadap motivasi kerja diperoleh nilai signifikansi 0,009 < 0,05 berarti ada pengaruh yang signifikan variabel kepuasan kerja terhadap motivasi kerja. Dengan demikian dapat disimpulkan $\mathrm{H}_{3}$ diterima, bahwa kepuasan kerja berpengaruh positif terhadap motivasi kerja karyawan di Balai Besar Pemberdayaan Masyarakat dan Desa Malang.

\section{Pembahasan}

Hasil analisis menjelaskan bahwa pengembangan karir akan mempengaruhi motivasi kerja karyawan, jadi adanya kesempatan pengembangan karir bagi karyawan di perusahaan ternyata berdampak pada tumbuhnya motivasi kerja karyawan. Kesempatan pengembangan karir tersebut dicerminkan dari adanya pengakuan terhadap prestasi kerja, eksposur, jaringan kerja, kesetiaan terhadap organisasi, pembimbing dan sponsor, serta peluang untuk tumbuh, adapun yang paling mendukung pengembangan karir tercermin dari kesetiaan para karyawan terhadap organisasi. Temuan lain penelitian bahwa pengembangan karir juga berpengaruh terhadap kepuasan kerja, selanjutnya kepuasan kerja akan mempengaruhi motivasi kerja. Jadi kesempatan pengembangan karir juga mampu menciptakan kepuasan kerja dalam diri karyawan, karena ada harapan bahwa kinerja yang baik akan membuahkan hasil berupa kejelasan karir karyawan di masa yang akan datang, sehingga motivasi kerja karyawan akan semakin meningkat.

Faktor yang membentuk motivasi kerja adalah kebutuhan fisiologis, kebutuhan rasa aman, kebutuhan social, kebutuhan penghargaan, kebutuhan aktualisasi diri. Adapun indikato yang paling tinggi dari motivasi kerja karyawan adalah dicerminkan dari terpenuhinya kebutuhan penghargaan dengan cara pegawai yang berprestasi diberi apresiasi penghargaan. Sedangkan kepuasan kerja selama ini paling banyak didukung dari faktor peralatan yang menunjang pekerjaan khususnya sarana dan prasarana yang layak digunakan.

Temuan penelititan ini sejalan dengan penelitian Kurniawan et al. (2018) dan Haryani (2012) menyatakan bahwa pengembangan karir berpengaruh terhadap motivasi kerja. Namun bertentangan dengan hasil penelitian Dewi \& Utama (2016) bahwa pengembangan karir tidak mempengaruhi motivasi. Penelitian ini juga memperkuat hasil penelitian Lisdiani \& Ngatno (2017), Akhmal et al. (2018) dan Bahri \& Nisa (2017) menyatakan bahwa pengembangan karir mempengaruhi kepuasan kerja karyawan, serta hasil penelitian Afifah \& Al Musadieq (2017) dan Lie (2018) bahwa kepuasan kerja akan mempengaruhi motivasi kerja karyawan. 


\section{Simpulan}

Pengembangan karir berpengaruh signifikan terhadap motivasi kerja melalui kepuasan kerja di Balai Besar Pemberdayaan Masyarakat dan Desa di Malang. Pengembangan karir dibentuk oleh prestasi kerja, eksposur, jaringan kerja, kesetiaan terhadap organisasi, pembimbing dan sponsor, peluang untuk tumbuh dengan nilai tertinggi pada pembimbing dan sponsor dengan adanya jenjang karir terhadap pegawai. Motivasi kerja ini dibentuk oleh kebutuhan fisiologis, kebutuhan rasa aman, kebutuhan social, kebutuhan penghargaan, kebutuhan aktualisasi diri. Dominan oleh kebutuhan penghargaan dengan memberikan penghargaan pada pegawai yang berprestasi. Kepuasan kerja dibentuk oleh komponen gaji dan upah, peralatan yang menunjang pekerjaan, promosi karir, dan hubungan dengan atasan, dominan pada peralatan yang menunjang pekerjaan dengan adanya sarana dan prasarana yang layak digunakan.

Pengembangan karir berpengaruh signifikan terhadap kepuasan kerja di Balai Besar Pemberdayaan Masyarakat dan Desa di Malang. sehingga kepuasan kerja pegawai tidak bisa dilepaskan dari upaya pengembangan karir. Pengembangan karir dibentuk oleh prestasi kerja, eksposur, jaringan kerja, kesetiaan terhadap organisasi, pembimbing dan sponsor, serta peluang untuk tumbuh. Dominan pada pembimbing dan sponsor dengan adanya jenjang karir terhadap pegawai. Pengembangan karir berpengaruh signifikan terhadap motivasi kerja karyawan di Balai Pemberdayaan Masyarakat dan Desa di Malang. sehingga meningkatnya motivasi kerja karyawan tidak dapat dilepaskan dari pengembangan karir. pengembangan karir di bentuk oleh kebutuhan fisiologis, kebutuhan rasa aman, kebutuhan social, kebutuhan penghargaan, serta kebutuhan aktualisasi diri, dominan pada kesetiaan terhadap organisasi dengan selalu menjaga nama baik organisasi.

Kepuasan kerja berpengaruh signifikan terhadap motivasi kerja karyawan di Balai Pemberdayaan Masyarakat dan Desa di Malang. Sehingga meningkatnya motivasi kerja karyawan tidak terlepas dari kepuasan kerja karyawan. Kepuasan kerja karyawan dibentuk oleh komponen gaji dan upah, sarana dan prasarana, peralatan yang menunjang pekerjaan, promosi karir, serta hubungan dengan atasan. Dominan pada peralatan yang menunjang pekerjaan dengan adanya sarana dan prasarana yang layak digunakan. 


\section{Daftar Pustaka}

Afifah, T., \& Al Musadieq, M. (2017). Pengaruh Kepuasan Kerja Terhadap Motivasi Kerja dan Dampaknya Terhadap Kinerja (Studi pada Karyawan PT Pertamina Geothermal Energy Kantor Pusat Jakarta). Jurnal Administrasi Bisnis, 47(1), $122-129$.

Akhmal, A., Laia, F., \& Sari, R. A. (2018). Pengaruh pengembangan karir terhadap kepuasan kerja karyawan. Jurnal Bis-A: Jurnal Bisnis Administrasi, 7(1), 20-24.

Bahri, S., \& Nisa, Y. C. (2017). Pengaruh Pengembangan Karir Dan Motivasi Kerja Terhadap Kepuasan Kerja Karyawan. Jurnal Ilmiah Manajemen Dan Bisnis, 18(1), 9-15.

Bianca, A., \& Susihono, W. (2012). Pengaruh iklim organisasi dan pengembangan karir terhadap kepuasan kerja karyawan. Spektrum Industri, 10(2).

Dewi, N. L. P. A. A., \& Utama, I. W. M. (2016). Pengaruh Pengembangan Karir Terhadap Kinerja Karyawan Melalui Mediasi Motivasi Kerja Pada Karya Mas Art Gallery. E-Jurnal Manajemen Universitas Udayana, 5(9).

Djamaludin, M. (2009). Pengaruh Komitmen Organisasional, Pengembangan Karier, Motivasi Kerja Dan Karakteristik Individual Terhadap Kepuasan Kerja Dan Kinerja Pegawai Pemerintah Kabupaten Halmahera Timur. Die: Jurnal Ilmu Ekonomi Dan Manajemen, 5(2).

Haryani, P. Y. (2012). Korelasi antara Pengembangan Karir dengan Motivasi Kerja dan Keinginan Untuk Pensiun Dini. Buletin Studi Ekonomi, 44239.

Hasibuan, M. S. P. (2016). Manajemen sumber daya manusia. Bumi Aksara.

Isyanto, P., \& Sungkono, C. D. (2013). Pengaruh Pengembangan Karir Karyawan Terhadap Motivasi Kerja Karyawan Pada PT. Excel Utama Indonesia Karawang. Jurnal Manajemen, 10(0), 3.

Kurniawan, A., Yunus, M., \& Majid, M. S. A. (2018). Pengaruh kompensasi dan pengembangan karir terhadap motivasi serta dampaknya pada kinerja karyawan PT. Bank Syariah Mandiri Cabang Banda Aceh. Jurnal Manajemen Inovasi, 8(2).

Lie, T. F. (2018). Pengaruh Kepuasan Kerja Terhadap Kinerja Karyawan Melalui Motivasi Kerja pada CV. Union Event Planner. Agora, 6(1).

Lisdiani, V., \& Ngatno, N. (2017). Pengaruh Pengembangan Karir terhadap Kepuasan Kerja Karyawan Melalui Motivasi Kerja Sebagai Variabel Intervening (Studi Kasus Pada Hotel Grasia Semarang). Jurnal Ilmu Administrasi Bisnis, 6(4), 105-112. 
Manoppo, R. (2015). Pengaruh Displin Kerja, Motivasi Kerjadan Pengembangan Karir terhadap Kepuasan Kerja pada Tvri Sulawesi Utara. Jurnal EMBA: Jurnal Riset Ekonomi, Manajemen, Bisnis Dan Akuntansi, 3(3).

Martoyo, S. (2007). Manajemen Sumber Daya Manusia. Yogyakarta: BPFE.

Mathis, R. L., \& Jackson, J. H. (2009). Human Resource Management: Manajemen Sumber Daya Manusia. Terjemahan Dian Angelia. Salemba Empat.

Rivai, Veithzal dan Sagala, E. J. (2009). Manajemen Sumber Daya Manusia untuk Perusahaan dari Teori ke Praktik. PT Raja Grafindo.

Rivai, V., \& Sagala, E. J. (2009). Manajemen Sumber Daya Manusia Untuk Perusahaan Edisi 2. Jakarta: PT. Raja Grafindo.

Sule, E. T., \& Saefullah, K. (2005). Pengantar Manajemen. Prenada Media. 